\title{
Evaluation by Rubrics: A Computerized System
}

\author{
Juan Cristobal Barrón1, Humberto Blanco', José René Blanco1, \\ Judith M. Rodríguez-Villalobos ${ }^{1 *}$, Jesús Viciana² \\ ${ }^{1}$ Faculty of Physical Culture Sciences, Autonomous University of Chihuahua, Chihuahua, Mexico \\ ${ }^{2}$ Department of Physical Education and Sport, University of Granada, Granada, Spain \\ Email: ${ }^{*}$ judithrv@gmail.com
}

Received 7 April 2014; revised 2 May 2014; accepted 22 May 2014

Copyright (C) 2014 by authors and Scientific Research Publishing Inc.

This work is licensed under the Creative Commons Attribution International License (CC BY). http://creativecommons.org/licenses/by/4.0/

c) (i) Open Access

\begin{abstract}
This report details a computerized system that allows teachers to use rubrics as a means of evaluation in a curriculum competency. The computerized system for evaluation by rubrics allows you to design them, modify them, and generate a bank with them so that they can be used later. It is a software that allows you to assess, co-assess, and self-assess either team or individually, the evidence of learning in a course through rubrics and represents an example of how the proper use of the new technologies can become a differentiating factor assessment process of learning about traditional evaluative practices by providing tools that allow use of time and material resources in a more effective and efficient manner both, for the teacher and the student.
\end{abstract}

\section{Keywords}

Rubrics, Curriculum Competency, Software, New Technologies

\section{Introduction}

At the end of the XX century, and the beginning of the XXI, a change is observed in the new technologies in many areas of life, the information and media. These last are closer every day to people in databases, information running around drowning us in seas of information that becomes a challenge to surf (Lei, Shen, \& Johnson, 2014; Roehrig, Groos, \& Guzey, 2014; Singley \& Taft, 1995). There has been a resounding change within society, leaving aside industrial society and builds on the information society, which emphasizes the value of the data produced and the power of knowledge as a means to change the reality; later the learning society suppose a step in it, and individuals must learn throughout life to survive. And finally, the intelligence society emphasizes

${ }^{*}$ Corresponding author. 
the idea of shared and distributed intelligence (Beltrán, 2011, 2013).

The use of the computer, among other things, allows extending the content being assessed, generating expert systems of correction, administration via Internet, the best items for certain assessment objectives (optimal tests) or to certain people (computerized adaptive tests) and so forth. We agree with Prieto, Carro, Orgaz, Pulido, and González-Tablas (1993) and Ishiyama and Watson (2014) in the sense that one of the important applications of personal computers is the construction and management of computerized tests that can replace some fields to the classic pencil and paper tests; allowing storage of data without pre-encoding steps with greater accuracy, speed, and immediate feedback when giving results; and facilitate registration latency time response to each item and the multimedia presentation, with the inclusion of texts, graphics, photographs and even videos and simulations.

It is also clear that automated systems allow for more accurate and reliable data, increasing speed and efficiency of the analysis, presentation and storage, thus untying the teaching routine and mechanical tasks, thereby promoting greater availability of time for other teaching tasks (Roland, 2006; Singley \& Taft, 1995; Warren, Lee, \& Najmi, 2014).

On the other hand, one of the undeniable characteristics of education systems today is the complexity of the learning goals proposed (Jonassen, 2014; Petropoulou, Vassilikopoulou, \& Retalis, 2011) since it is the assessment whose goal is to corroborate these learning objectives as well as identify the factors that influence or affect such learning, without neglecting the quality and improvement of the educational intervention (Marín, Guzmán, \& Castro, 2012), to evaluate becomes a complex and overwhelming process for teachers. And it is this context where the rubrics describing the degree to which a learner is running a process or a product based on clear and consistent performance criteria, allow to monitor and self-assess learning product, reducing the subjectivity in evaluating and helping to identify errors, understand their causes and make decisions to overcome them turning them into essential tools to ensure that the evaluation is integrated into everyday classroom processes, be continuous, encourage feedback and be coherent within the teaching-learning process (Petropoulou et al., 2011; Roland, 2006).

Therefore, this current project describes a computerized system designed to facilitate the use of rubrics as a means of evaluation, self-assessment and co-assessment; that is a system designed to improve the assessment process in an educational program established with competence approach.

\section{Method}

Next, the steps performed in the design of the Computerized Assessment System for Learning by Rubrics (SIEAR) are specified.

\subsection{Analysis}

At this stage, several discussion meetings of the research group were defined in detail the components and functions of the Computerized Assessment System for Learning by Rubrics (SIEAR) to be taken into account in their design.

\subsection{Beta Version: Design and Testing of SIEAR}

Once the new editor was technically finished and steady enough to work normally, tests were done to identify either the features and/or functions that would require to be modified.

\subsection{Design and Testing of Version 1.0 of SIEAR}

Once the corrections and modifications were made to that of the beta version, a free error software was achieved with a quality, suitable to be used by latter users. This version was again subjected to tests to identify the features and functions that needed to be corrected.

\subsection{Design Module Installation SIEAR}

After reaching Version 1.0 soft ware package using Install Shield 5.5 Professional Edition installer new editor was designed for distribution to latter users. 


\subsection{Overview SIEAR}

The Automated System for the Assessment of Learning Through Rubrics (SIEAR) is a software that allows to assess, co-assess and self-assess in a teaching course, either team or individually the evidence of learning by rubrics. It consists of six modules: Builder of the course structure, rubrics Builder, Settings, Learning Assessment, Reporting and System Generator.

The Figure 1 shows the module builder of the course structure, in addition to allowing define the general characteristics of the course: name, authors, sections, students, teachers, evidence of learning.

Builder module rubrics allow design, import, and/or customize the rubrics by which the evidence of learning each of the activities proposed in the course will be evaluated, see Figure 2.

Figure 3 contains the configuration module allows predetermine some relevant characteristics of the user interface as colors, font size, coordinates, etc.

The learning assessment module, besides being the user interface; allows assessing, co-assessing, and self-assessing either team or individually the learning evidence of the course and storing the results of evaluations, self-assessments or co-assessments made; see Figure 4.

Figure 5 shows the module reports, besides focusing and displaying the results of assessments, co-assessments, or self-assessments made, allows to support them in a destination different than the original.

The generator system module, allows to copy, either aim is selected, the files that establish the Computerized Assessment System for Learning and Using Rubrics to be used in the course for which it was designed; it is illustrated in Figure 6.

\section{Graphical Modeling Procedure for Using the Software}

Step 1: Define the overall course structure and enrollment of students and teachers; see Figure 7.

Step 2: Design of learning activities, evidence of performance, assessments and rubrics; it is illustrated in Figure 8.

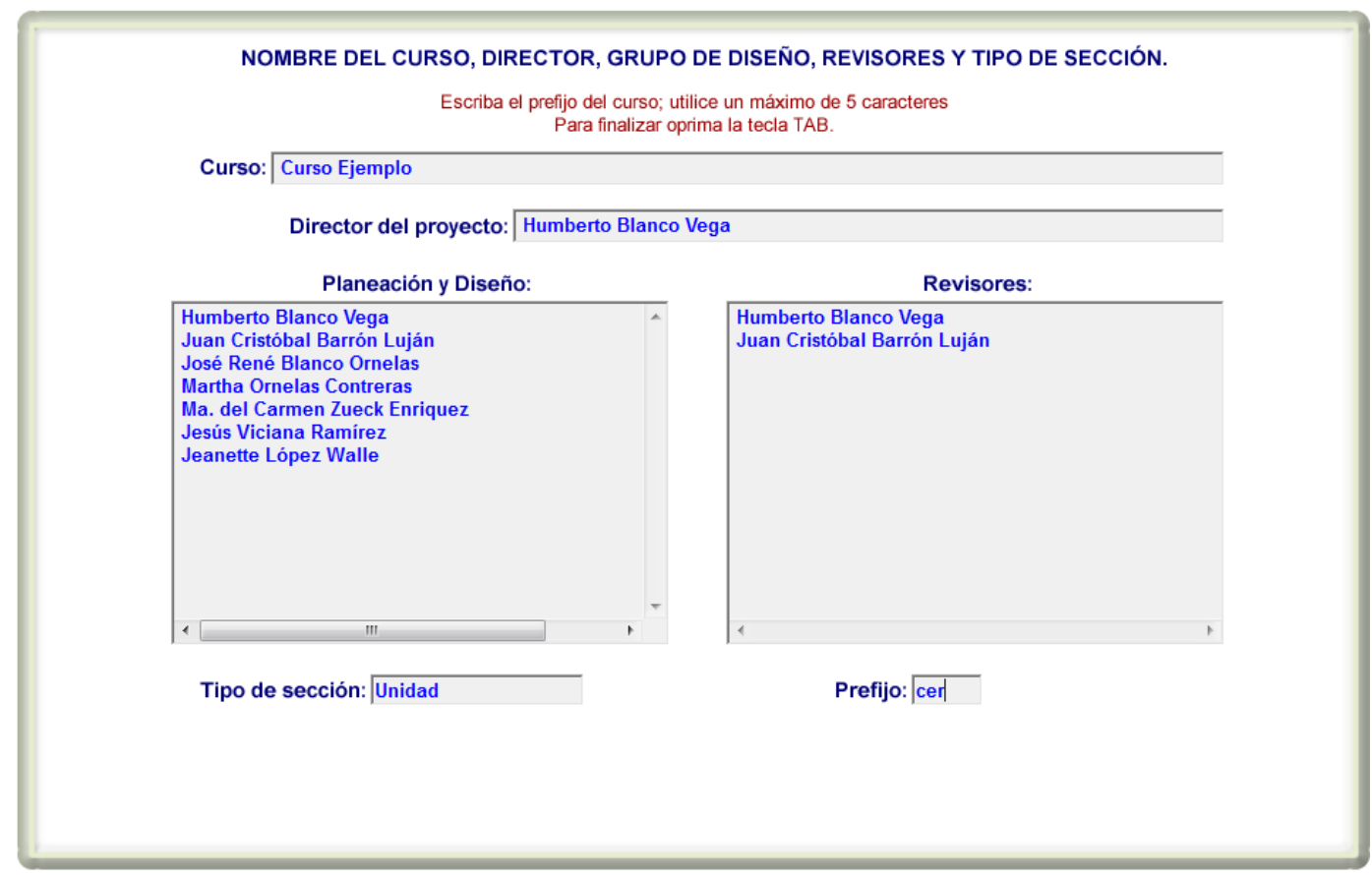




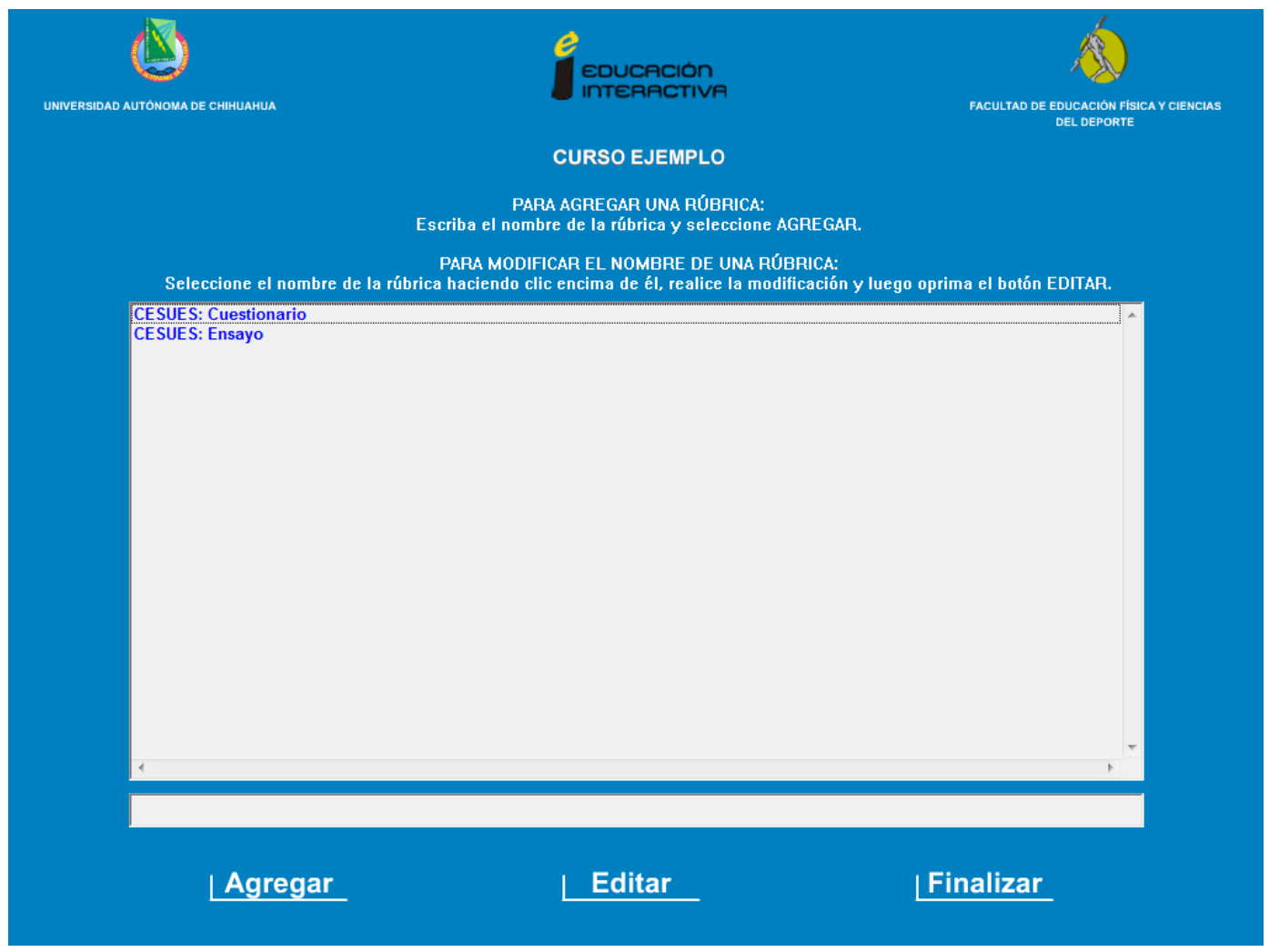

Figure 2. Displayedit rubrics, rubric builder module.

\section{Configuración de la interfaz del usuario}

Por favor, realice las modificaciones que considere necesarias a la interfaz del usuario. Para finalizar seleccione el botón SALIR.

Color Fondo:

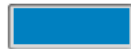

Color Franja:

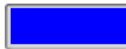

Color Botones:

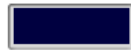

Color Avisos:

Formato de los Logos: $\frac{}{\text { Imagen JPG }}$

CON COMPLEMENTO

\begin{tabular}{|c|c|c|c|c|c|c|}
\hline & \multicolumn{5}{|c|}{ CON COMPLEMENTO } \\
\hline & & Fuente & Ancho & Alto & $\mathrm{x}$ & Y/sep \\
\hline $\begin{array}{l}\mathrm{P} \\
\mathrm{R}\end{array}$ & RB & $14 \div$ & $600 \div$ & $80 \div$ & $400 \div$ & $220 \div$ \\
\hline $\mathrm{E}$ & OM & 14 & 600 & 80 & 400 & 220 \\
\hline $\mathrm{N}$ & $\mathrm{FV}$ & 14 & 600 & 80 & 400 & 220 \\
\hline A & LAG & 14 & 600 & $26 \div$ & 400 & 220 \\
\hline $\begin{array}{l}\mathrm{R} \\
\mathrm{E}\end{array}$ & RB & 14 & 600 & $115 \div$ & 400 & $30 \div$ \\
\hline $\begin{array}{l}P \\
u\end{array}$ & OM & 14 & 600 & 115 & 400 & 30 \\
\hline $\begin{array}{l}\text { E } \\
\text { S }\end{array}$ & $\mathrm{FV}$ & 14 & $360 \div$ & 26 & $540 \div$ & 30 \\
\hline A & LAG & 14 & 600 & 26 & 400 & $14 \div$ \\
\hline
\end{tabular}

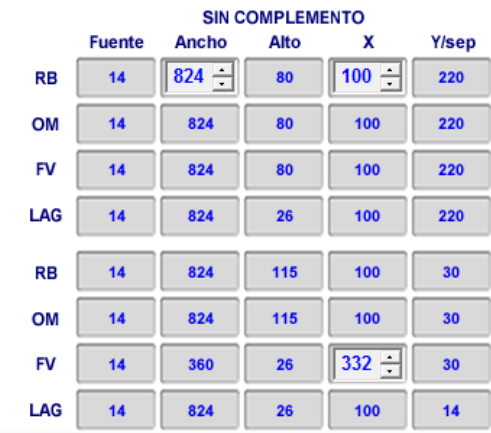

Figure 3. Configuration menu of SIEAR interface, module configuration menu. 
AUtOEVAlUACIón INDIVIDUAL Actividad 1 Unidad 1: Evidencia 2 de la Actividad 1

$$
\begin{aligned}
& \text { ACtualmente SE Encuentra EVALuAndo A: } \\
& \text { Ornelas Contreras José René } 1001 \\
& \text { Aspecto } 1 \text { de } 5 \text { Ponderacion } 20 \%
\end{aligned}
$$

\section{Definición del problema}

(10) Competente sobresaliente El problema planteado esta muy bien definido y delimitado

(9) Competente avanzando El problema planteado esta bien definido y delimitado

(8) Competente intermedio El problema planteado esta definido y delimitado de manera regular

(7) Competente básico El problema planteado esta mal definido y delimitado

(6) Aún no competente No hay definición ni delimitación del problema planteado

Figure 4. LCD for assessing aspects of the rubric, learning assessment module.

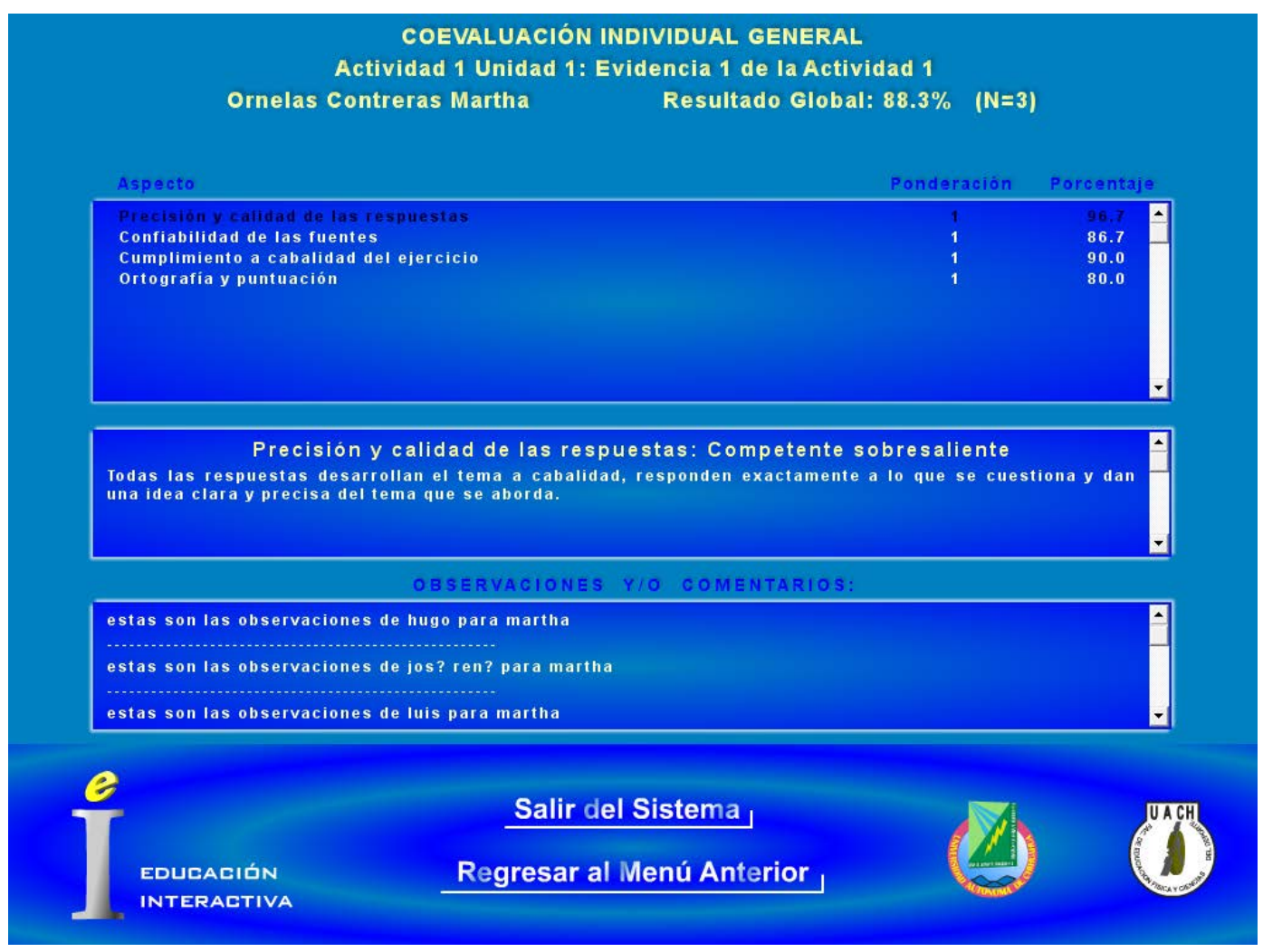

Figure 5. Menu results of the assessment of evidence, reports module. 
SELECCIONE LA CARPETA DONDE DESEA COPIAR LOS ARCHIVOS DE LAS VERSIONES LOCAL Y WEB:

Sistema Informatizado para la Evaluación del Aprendizaje Mediante Rúbricas

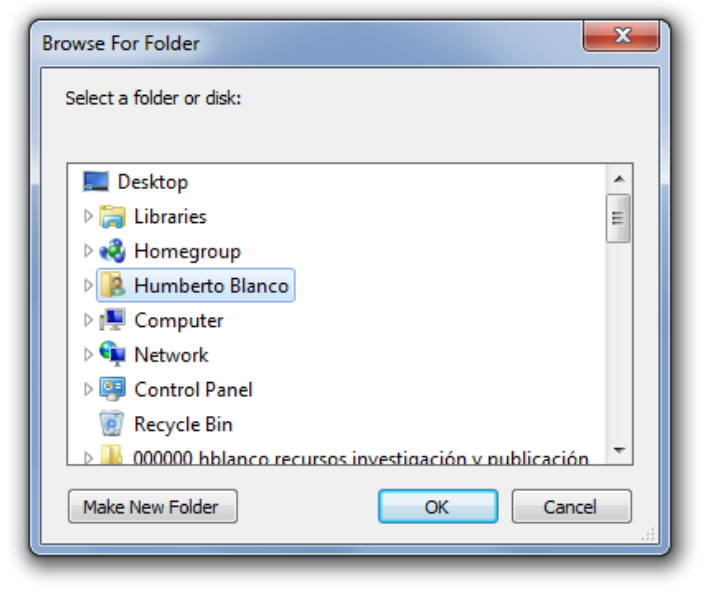

Figure 6. Screen: Where do you want to copy the files locally and web versions? Generator module system..

Step 3: You can see in Figure 9 the self-assessments and/or co-student assessments and teacher evaluations for each performance evidence.

Step 4: Browse by the students and teacher reports on the results of evaluations, self-assessments and co-evaluations conducted; see Figure 10.

\section{Conclusions}

We believe that the main contribution of this type of software in the field of evaluation in education, basically represents a viable and effective computer use in the development, administration and scoring of assessment instruments example, which affects mainly the reliability of the data, besides the stage of collecting and reporting the results is carried out with relative ease and economy of time.

The Automated System for the Assessment of Learning Through Headings (SIEAR) favors the teaching-learning process because it acts as a guide, and improves the evaluation process as it allows him greater objectivity and transparency, making the tax assessment and not become a feedback tool that allows the student to have clear performance standards and discover specific aspects in which a greater effort must be made.

The SIEAR as such represents a good example of how the use of new technologies can become a differentiator in the process of learning assessment over traditional assessment practices by providing tools to use the resources of time and materials so more effectively and efficiently by both the teacher and the student. The prospects for new versions allow SIEAR thinking, among other things, expand the contents under assessment, and generate expert systems of correction.

\section{Acknowledgements}

This study is part of a project funded by the Secretaría de EducaciónPública-Subsecretaría de Educación Supe- 
NOMBRE DEL CURSO, DIRECTOR, GRUPO DE DISEÑO, REVISORES Y TIPO DE SECCIÓN.

Escriba el prefijo del curso: utilice un máximo de 5 caracteres

Para finalizar oprima la tecla TAB.

Curso: Curso Ejemplo

Director del proyecto: Humberto Blanco Vega

Planeación y Diseño:

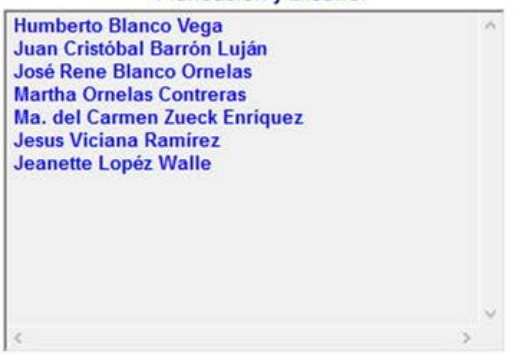

Tipo de sección: Unidad
Revisores:

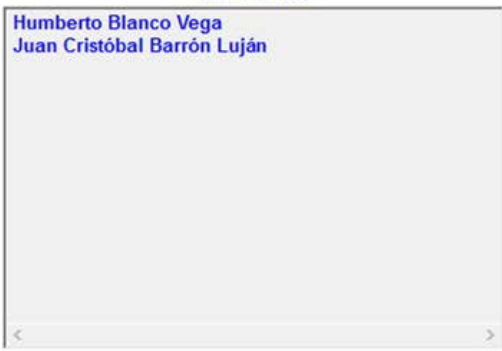

Prefijo: cer

SIGUIENTE

(a)

\section{NOMBRES SECCIONES}

Escriba el nombre de cada una de las Secciones.

Después de cada nombre oprima la tecla ENTER y para finalizar TAB.

Secciones:

\section{Unidad \#1}

Unidad \#

Unidad \# 3

Unidad \#4

(b) 


\section{NOMBRE Y PUESTO DE CADA INTEGRANTE DEL DIRECTORIO}

Escriba un nombre (utilice mayúsculas y minúsculas) y oprima la tecla ENTER. En seguida el puesto (utilice puras mayúsculas) y oprima la tecla ENTER; y asi sucesivamente.

M. C. Jesús Enrique Seáñez Sáenz

RECTOR DE LA UACH

M. D. Saúl Arnulfo Martínez Campos

SECRETARIO GENERAL DE LA UACH

Dr. Alejandro Chávez Guerrero

DIRECTOR ACADÉMICO DE LA UACH

M. C. Francisco Javier Flores Rico

DIRECTOR DE LA FEFCD

Dr. Jesús Enrique Peinado Pèrez

SECRETARIO ACADÉMICO DE LA FEFCD

Dra. Martha Ornelas Contreras

COORDINADORA DE LICENCIATURA EN MOTRICIDAD HUMANA

M. C. Ramón Candia Luján

COORDINADOR DE LICENCIATURA EN EDUCACIÓN FISICA

$$
\text { | }
$$

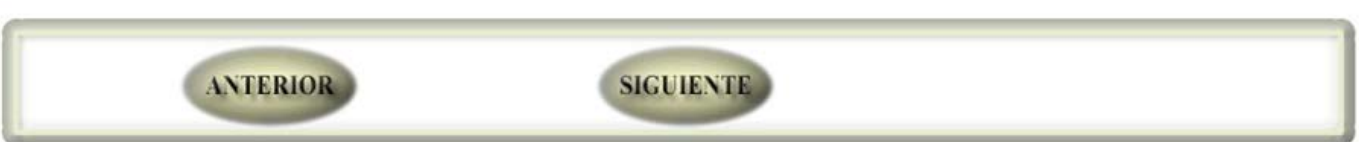

(c)

\section{ALTAS Y MODIFICACIONES}

Docentes

Por favor, escriba el APELLIDO PATERNO del profesor, y enseguida oprima la tecla TAB o la tecla ENTER.

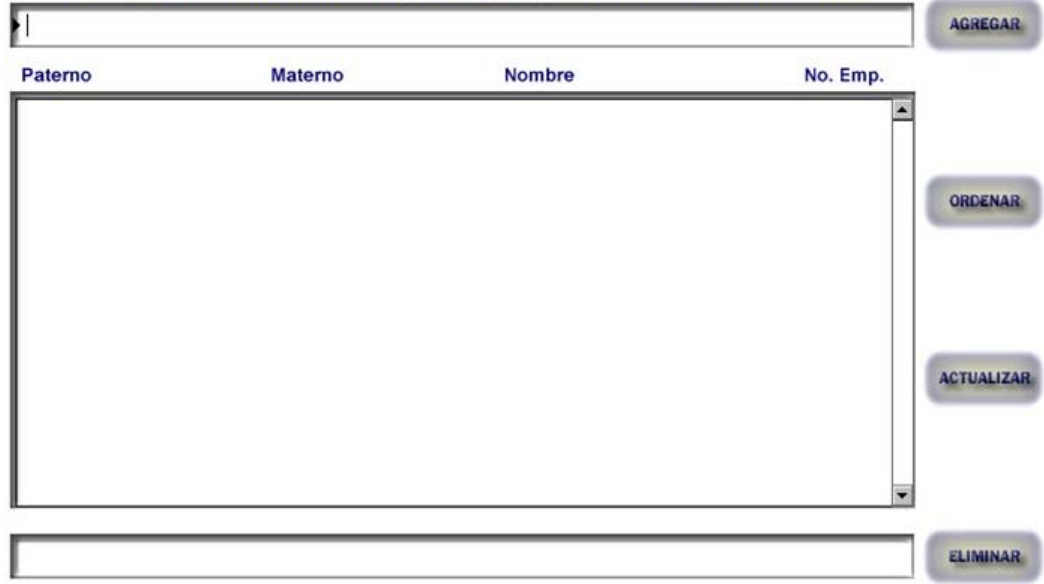

(d) 


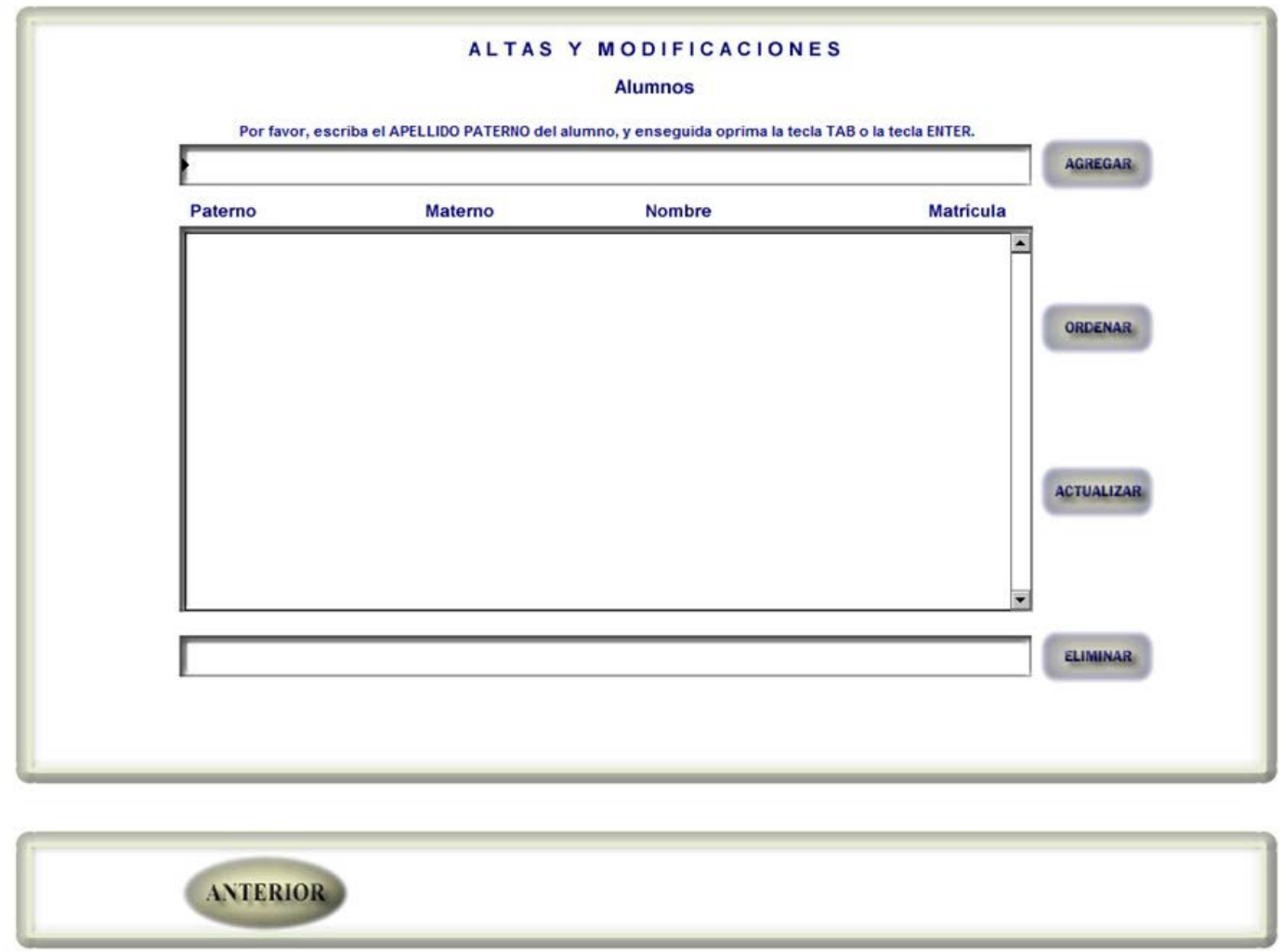

(e)
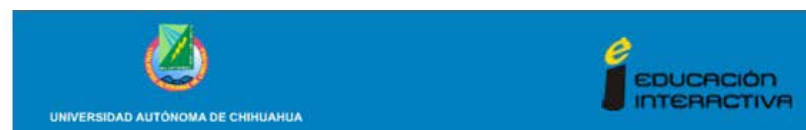

FACULTAO DE EDUCACION FISICA Y CIENCUS

UNVERSIOAO AUTONOMA DE CHHUAHUA

EDuCAción

Curso Ejemplo

Figure 7. Screens of builder module course structure (part one). 


\section{EDITOR PARA EVALUACIÓN DE EVIDENCIAS DE DESEMPEÑO}

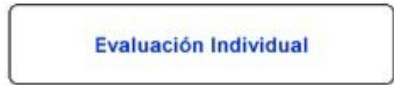

Autoevaluación Individua

Coevaluación Individual General

Coevaluación Individual Parcial

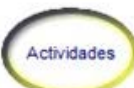

\section{Evaluación Equipo}

Autoevaluación Equipo

Coevaluación Equipo General

Coevaluación Equipo Parcial

\section{ACTIVIDADES PARA: UNIDAD \# 1}

Escriba el nombre de cada una de las actividades para el Objeto de Estudio: UNIDAD \# 1 Después de cada nombre oprima la tecla ENTER y para finalizar seleccione el Botón Actualizar.

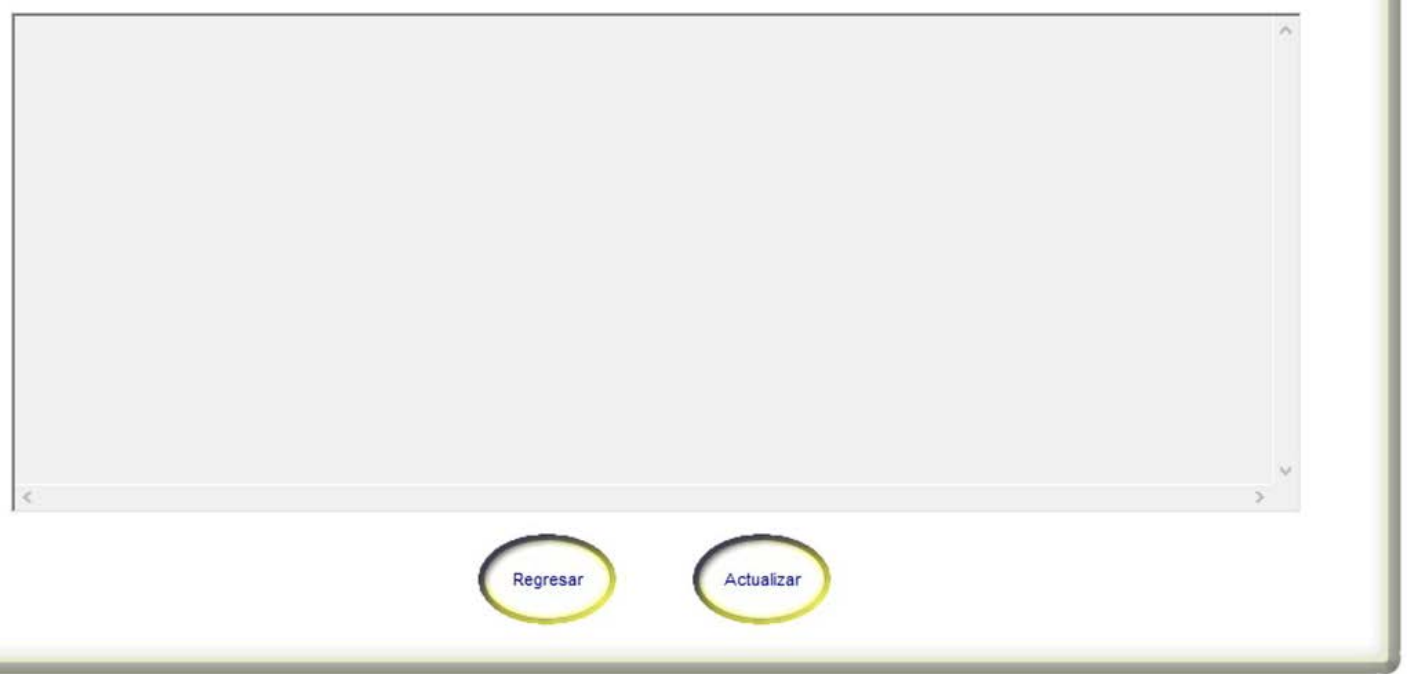

(b) 


\section{ACTIVIDADES Y EVIDENCIAS PARA: UNIDAD \# 1}

\section{Actividades:}

Actividad 1. Unidad \#1

Actividad 2. Unidad \# 1

Nombre de la evidencia:

Evidencia 2 de la Actividad 1

Evidencias:

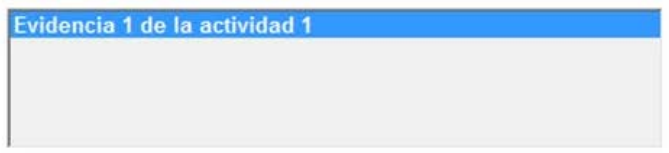

Eliminar
Escriba la descripción para la evidencia seleccionada Al terminar oprima el botón Actualizar.
Agregar

Descripción de la evidencia:

Esta es la descripción de la evidencia de la actividad 1 de la unidad 1

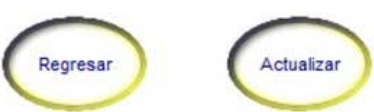

(c)

Valoraciones

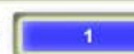

Tipo

EI

Valoración \#

Tipo de Valoración Elegida: Evaluación Individual

Seleccione el nombre de la evidencia de desempeño para la que va a diseñar la valoración Al terminar oprima la tecla TAB.

Actividades:

\section{Actividad 1. Unidad $\# 1$}

Actividad 2. Unidad \# 1

Evidencias:

Evidencia 1 de la actividad 1

\section{Rúbricas:}

CESUES: Paráfrasis

CESUES: Cuestionario

CESUES: Entrevista
Descripción de la evidencia:

Esta es la descripción de la evidencia de la actividad 1 de la unidad 1

Fecha de termino:

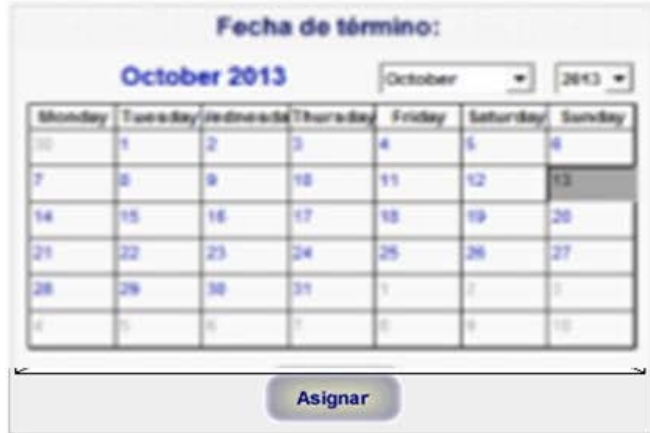

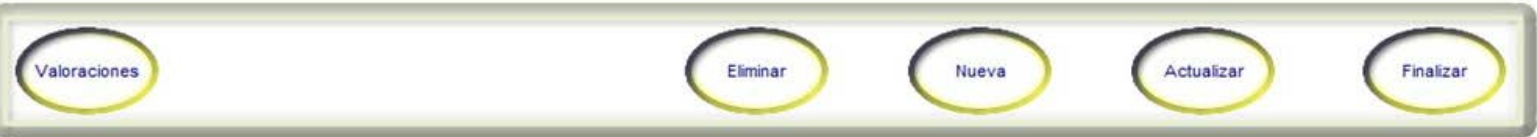

(d) 


\section{GENERAR EQUIPOS PARA:}

Actividad 1. Unidad \#1

Evidencia 1 de la actividad 1

Escriba o seleccione el número de equipos para la valoración que está diseñando

Al terminar oprima la tecla TAB.

Alumnos Inscritos: 4

No. Equipos: $2 \div$

\section{Método: $\begin{aligned} & \text { Aleatorio } \\ & \text { No Aleatorio }\end{aligned}$}

Clonación

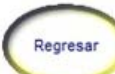

(e)

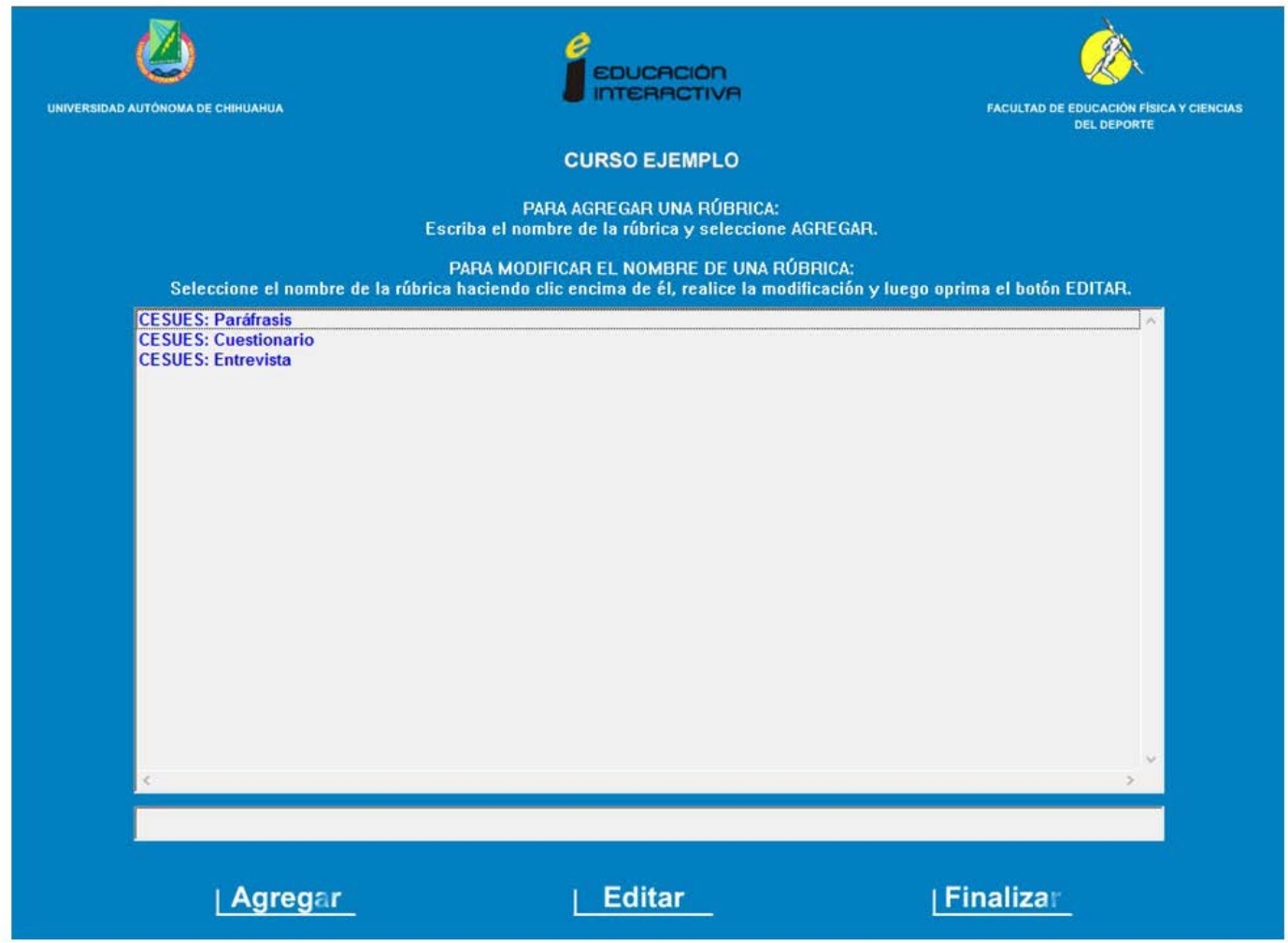

(f)

Figure 8. Screens of builder module course structure (part two). 


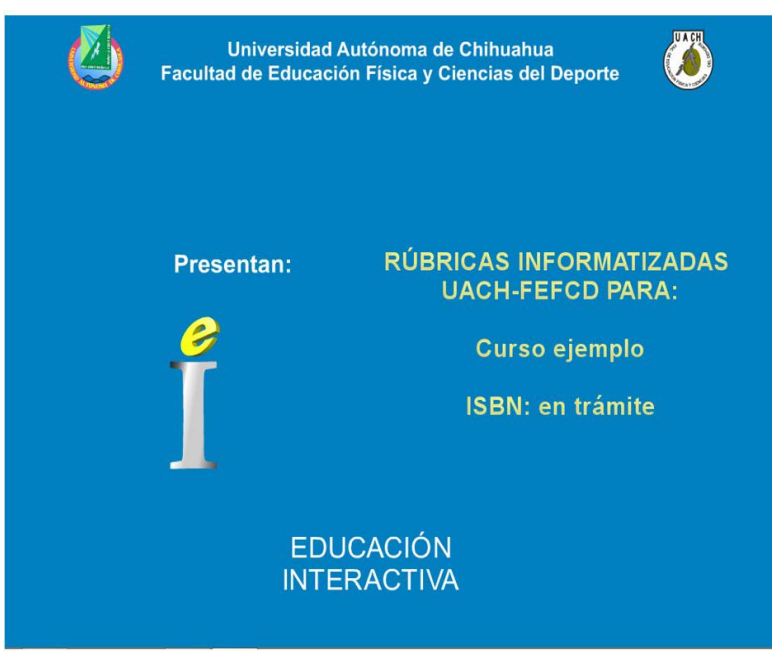

(a)

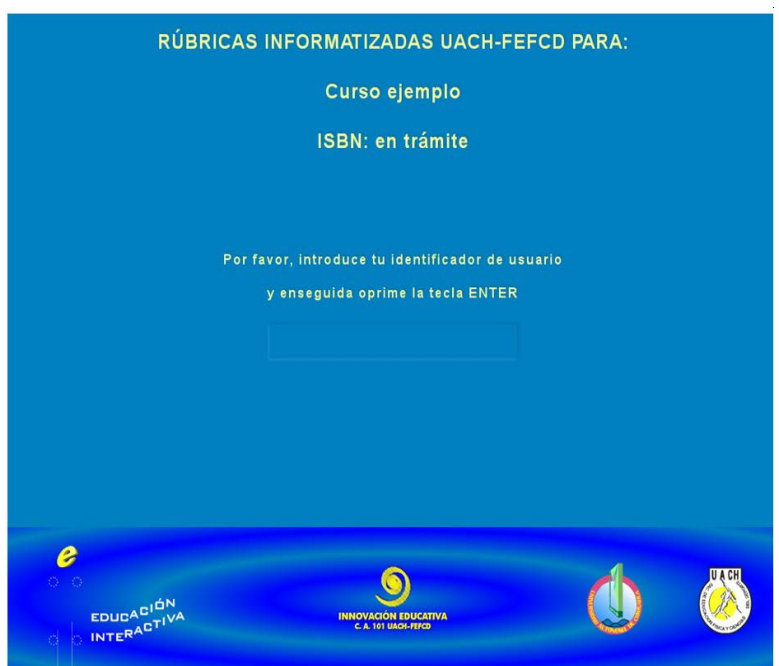

(c)

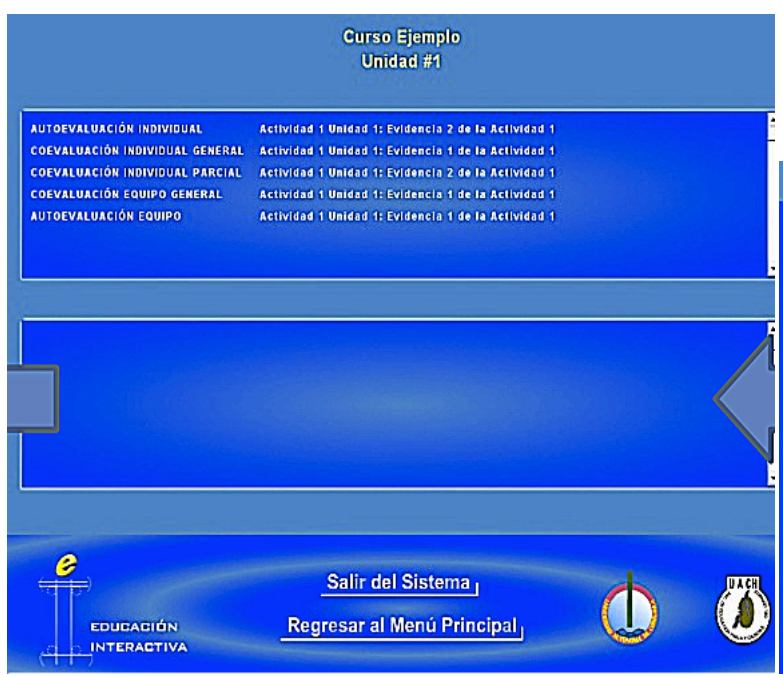

(e)

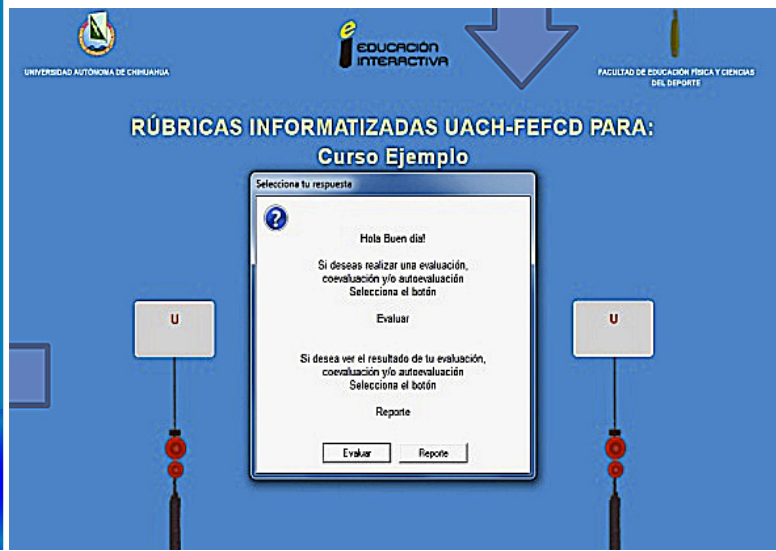

(d)

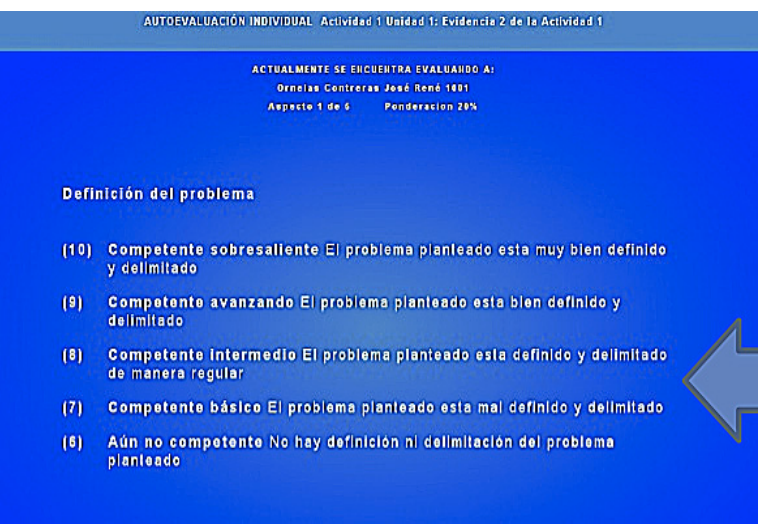

(f)

Figure 9. Screens of learning assessment module.. 


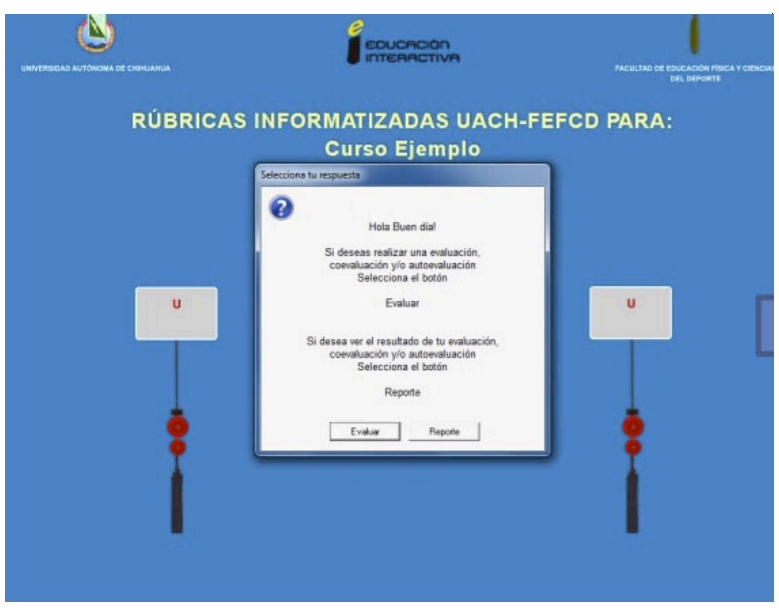

(a)

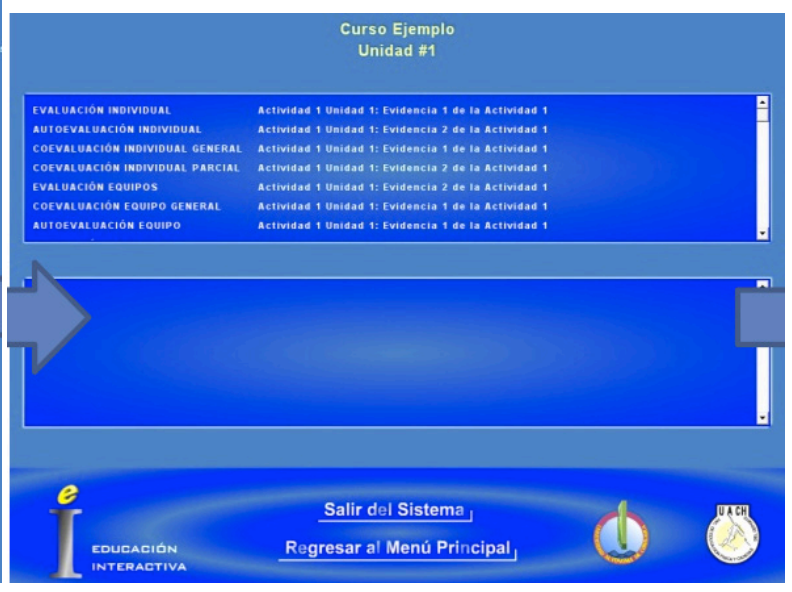

(b)

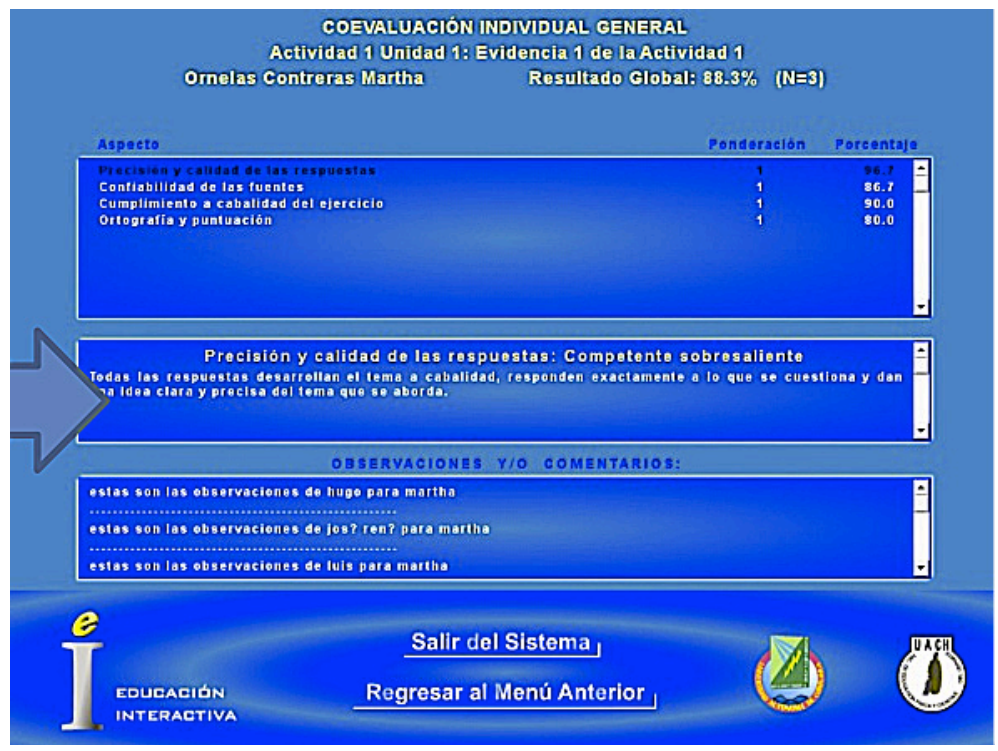

(c)

Figure 10. Screens of evaluation reports.

rior-Dirección General de Educación Superior Universitaria de México [Mexican Ministry of Education-Department of Higher Education-General Directorate of the University Education] (OF-13-6894). Additionally, the third author is supported by a grant from the National Council of Science and Technology of Mexico (Conacyt).

\section{References}

Beltrán, J. A. (2011). La educación inclusiva. Padres y Maestros, 338, 5-9.

Beltrán, J. A. (2013). La educación como cambio. Revista española de pedagogía, 71, 101-118.

Ishiyama, J., \& Watson, W. L. (2014). Using Computer-Based Writing Software to Facilitate Writing Assignments in Large Political Science Classes. Journal of Political Science Education, 10, 93-101. http://dx.doi.org/10.1080/15512169.2013.859085

Jonassen, D. H. (2014). Assessing Problem Solving. In J. M. Spector, M. D. Merrill, J. Elen, \& M. J. Bishop (Eds.), Handbook of Research on Educational Communications and Technology (pp. 269-288). New York: Springer. http://dx.doi.org/10.1007/978-1-4614-3185-5_22

Lei, J., Shen, J., \& Johnson, L. (2014). Digital Technologies and Assessment in the Twenty-First-Century Schooling. Contemporary Trends and Issues in Science Education, 41, 185-200. http://dx.doi.org/10.1007/978-94-007-2748-9_13 
Marín, R., Guzmán, I., \& Castro, G. (2012). Diseño y validación de un instrumento para la evaluación de competencias en preescolar. Revista Electrónica De Investigación Educativa, 14, 182-202.

Petropoulou, O., Vassilikopoulou, M., \& Retalis, S. (2011). Enriched Assessment Rubrics: A New Medium for Enabling Teachers to Easily Assess Student's Performance When Participating in Complex Interactive Learning Scenarios. Operational Research, 11, 171-186. http://dx.doi.org/10.1007/s12351-009-0047-5

Prieto, G., Carro, J., Orgaz, B., Pulido, R. F., \& González-Tablas, M. (1993). Uso del hypercard para la construcción de tests informatizados de aptitudes espaciales. Psicológica, 14, 229-237.

Roehrig, G. H., Groos, D., \& Guzey, S. S. (2014). Developing Collective Decision-Making Through Future Learning Environments. Contemporary Trends and Issues in Science Education, 41, 227-242. http://dx.doi.org/10.1007/978-94-007-2748-9_16

Roland, J. (2006). Measuring up: Online Technology Assessment Tools Ease the Teacher's Burden and Help Students Learn. Learning \& Leading with Technology, 34, 12-17.

Singley, M. K., \& Taft, H. L. (1995). Open-Ended Approaches to Science Assessment Using Computers. Journal of Science Education and Technology, 4, 7-20. http://dx.doi.org/10.1007/BF02211577

Warren, S. J., Lee, J., \& Najmi, A. (2014). The Impact of Technology and Theory on Instructional Design Since 2000. In J. M. Spector, M. D. Merrill, J. Elen, \& M. J. Bishop (Eds.), Handbook of Research on Educational Communications and Technology (pp. 89-99). New York: Springer. http://dx.doi.org/10.1007/978-1-4614-3185-5_8. 
Scientific Research Publishing (SCIRP) is one of the largest Open Access journal publishers. It is currently publishing more than 200 open access, online, peer-reviewed journals covering a wide range of academic disciplines. SCIRP serves the worldwide academic communities and contributes to the progress and application of science with its publication.

Other selected journals from SCIRP are listed as below. Submit your manuscript to us via either submit@scirp.org or Online Submission Portal.
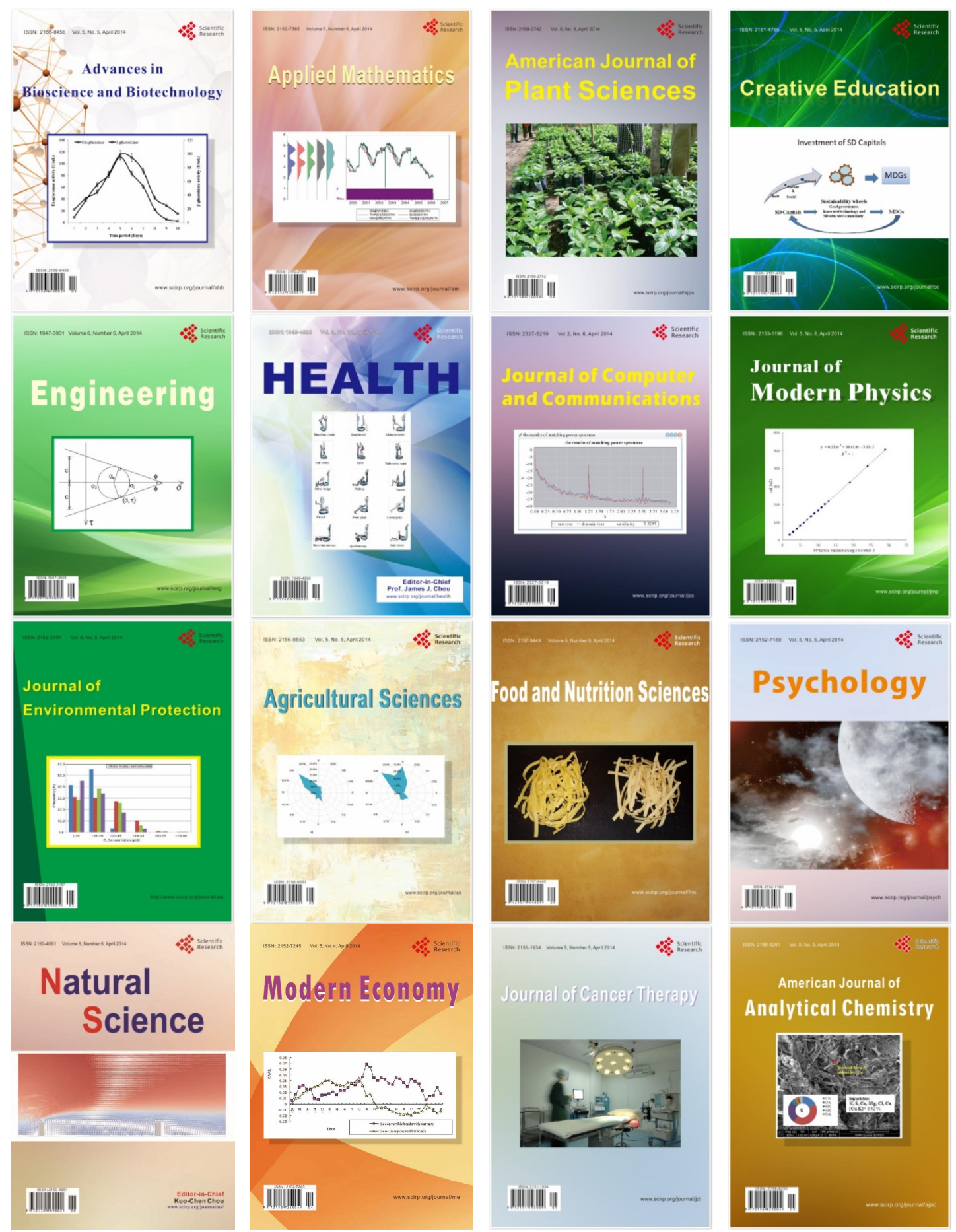